\title{
Pathological and Bacteriological Assessment of Reproductive Organ Disorders in She Camels in Somali, Eastern Ethiopia
}

\author{
Asnakew Chekole' \\ Abaynew Gelaye ${ }^{2}$ \\ Haben Fesseha iD $^{3}$ \\ Mesfin Mathewos (iD ${ }^{3}$ \\ 'Guna Begemdir District Veterinary \\ Clinic, Debre Tabor, South Gondar Zone, \\ Amhara Region, North-Central Ethiopia; \\ ${ }^{2}$ Guangua District Veterinary Clinic, \\ Injibara, Awi Zone, Amhara Region, \\ Northwest Ethiopia; ${ }^{3}$ School of \\ Veterinary Medicine, Wolaita Sodo \\ University, Wolaita Sodo, Ethiopia
}

Correspondence: Haben Fesseha Email haben.senbetu@wsu.edu.et
Background: Reproduction is a vital necessity for effective livestock production, and its productivity depends on the normal structure and function of the genital organs.

Methods: A study was carried out to characterize gross pathological lesions and identify aerobic bacteria from reproductive organ disorders of slaughtered she-camels (Camelus dromedarius) in the Fafen zone of the Somali Regional States of Ethiopia. All the available reproductive organ (50) samples were considered during sampling and cultured bacteriologically using a standard procedure.

Results: Accordingly, eighteen out of fifty female dromedary camels $(36 \%, 18 / 50)$ were found to have gross pathological lesions on the genitalia, including acute metritis $(10 \%)$, pyometra $(8 \%)$, cervicitis $(6 \%)$, vaginitis (4\%), follicular cysts $(4 \%)$, inactive/hypoplastic ovaries $(2 \%)$ and vaginal lymphocytic masses $(2 \%)$. Based on the anatomical distribution of reproductive tract lesions, uterine abnormalities were the most frequently observed lesions $(18 \%, 9 / 50)$, followed by cervicovaginal abnormalities $(12 \%, 6 / 50)$ and ovarian abnormalities $(6 \%, 3 / 50)$. In addition, eight different species of bacteria were identified from the sampled reproductive organs: 29 $(58 \%)$ from the uterus, 7 (14\%) from the cervix, 7 (14\%) from the vagina, 4 (8\%) from the udder, and $3(6 \%)$ from the ovary. Of the total isolated bacteria, coagulase-negative Staphylococcus species 25 (50\%), Staphylococcus aureus 18 (36\%), E. coli 12 (24\%), Streptococcus species 11 (22\%), Salmonella species 6 (12\%), Proteus species $8(16 \%)$, Shigella species $2(4 \%)$ and Klebsiella species $1(2 \%)$ were the most commonly identified bacterial species.

Conclusion: The study revealed that gross lesions of reproductive tracts and their bacterial isolates are prevalent in female dromedary camels. The role of each reproductive tract lesion and bacterial isolate as causes of reproductive failure in camels requires further investigation.

Keywords: bacterial isolates, dromedary camel, pathological lesion, reproductive disorder

\section{Introduction}

Globally, there are approximately 22 million camels, $89 \%$ of which are one-humped camels (Camelus dromedarius). East African countries such as Somalia, Sudan, Ethiopia, Kenya, Djibouti, and Eritrea are home countries to a proportionally greater number of one-humped camels than the rest of the world. ${ }^{1}$ In addition to Somalia and Sudan, Ethiopia is ranked third in Africa, with an estimated camel population of 2.4 million, and these camels are mainly located in lowland areas of the Beja, Rashaida, Somali, Afar, and Oromia Regional States. ${ }^{1,2}$ Despite its significant importance to the existence of pastoralist societies with limited 
alternative ways of production, the camel has been one of Ethiopia's most overlooked domestic animals by the scientific community until recently. ${ }^{3,4}$

The dromedary camel is a multipurpose animal found mostly in the pastoral areas of Ethiopia's southern, eastern, and northeast regions, ${ }^{4,5}$ and is the primary source of milk, meat, wool, hides, and skin in pastoral areas, such as Afar, Somali and Borana areas, especially during the dry season, where cattle milk is scarce. ${ }^{6-8} \mathrm{Camel}$ is considered a desert ship due to its special adaptability in arid and semiarid pastoral areas of eastern Ethiopia, where water and feed are minimal. ${ }^{9-11}$

At present, camels have been one of Ethiopia's export animals, even though their productivity faces multifaceted challenges due to infections causing several reproductive organ disorders leading to infertility or poor reproductive efficiency. ${ }^{12-16}$ In moving herds, calving rates of camels rarely reach $40 \%$, whereas they reach $70 \%$ in more intensively controlled herds. ${ }^{16}$ To produce genetically superior animals, emphasis should be directed towards better veterinary care and production systems. ${ }^{17}$ Some investigations conducted on reproductive organs have identified several types of uterine disorders that may result in reduced fertility in camelids. ${ }^{18,19}$ The types and occurrence of reproductive disorders in she-camels are investigated in limited studies, particularly those that relate clinical manifestations with the actual causes of infertility. ${ }^{20}$ The real causes of camel infertility have been suggested to be uterine infections, ovulation failure, and poor husbandry practices. ${ }^{21}$

Uterine infections in female camels are mostly caused by postpartum problems and an unhygienic approach to reproductive organs during therapy. ${ }^{15}$ Severe uterine inflammation has been linked to aggressive mating during the wrong stage of follicular development. ${ }^{22,23}$ Other problems in management include breeding with a young male, repeated use of males, and a lack of intromission during copulation. ${ }^{24}$

Identifying the causative agents and assessing their susceptibility to various medications often helps practitioners select the most appropriate medication; ${ }^{25}$ in this regard, among problems that significantly impact camel reproductive health, various bacterial diseases of the camel reproductive system are known to take Lion's share. Fayed and Refai $^{26}$ reported acute catarrhal or suppurative endometritis, chronic endometritis, pyometra, and abscesses of the uterine wall as the main genital tract infections of camels. In addition, abortions in camels were caused by Salmonella spp., Proteus spp., E. coli, Staphylococcus aureus, Klebsiella spp., Staphylococcus spp., Streptococcus spp.,
Streptococcus pyogenes, Pasteurella multocida, Serratia spp., Pseudomonas spp., and Corynebacterium pyogenes, and all these were isolated from cases of endometritis associated with pyometra in she-camels slaughtered at Cairo abattoir.

A major cause of economic losses connected with infertility, culling, and slaughtering in several mammalian species, including dromedary camels, ${ }^{27-29}$, is various infectious diseases and pathological lesions in the female genital system. ${ }^{30,31}$ As a result, abattoirs are a suitable place to look for pathological lesions of the reproductive organs that can lead to infertility or even sterility. Furthermore, the majority of female reproductive organ problematic lesions have no extra outward signs. As a result, postmortem abattoir-based surveys are important to discover the majority of these reproductive anomalies. ${ }^{13,32}$ The investigation of gross and microscopic genital tract lesions thus plays a critical role in the detection of these issues.

Abattoir-based research on camel and cow reproductive organ abnormalities, such as lesions of the uterus, ovary, oviduct, cervix, and vagina, has previously been described in numerous regions of the world, including Ethiopia. ${ }^{33-35}$ Ovariobursal adhesion, follicular cyst, luteal cyst, paraovarian cyst, ovarian hypoplasia, vaginitis, cervicitis, hydrosalpinx, pyosalpinx, hydrometra, endometritis, cervical ring hypoplasia, and uterine hypoplasia were some of the pathological abnormalities seen in most prior research in Ethiopia $^{28,29,36,37}$ and other camel-rating countries, such as Egypt, ${ }^{30}$ Saudi Arabia, ${ }^{38,39}$ Nigeria, $^{40}$ Algeria, ${ }^{41,42}$ Iraq $^{43}$ and Pakistan. ${ }^{44}$ Most previous studies revealed that uterine lesions were the most frequently encountered reproductive organ disorders in camels and cows. ${ }^{39,41,43,45-47}$ However, there is little published information about the reproductive problem of female dromedary camels in Ethiopia. ${ }^{28}$ Thus, this investigation aims to assess gross pathological lesions and isolate aerobic bacterial pathogens from reproductive organ disorders of she-camels in the Fafen zone of Somali Regional State, Eastern Ethiopia.

\section{Materials and Methods \\ Study Area}

The study was performed in the Fafen zone of the Ethiopian Somali Regional State (ESRS) from November 2017 to April 2018. Jigjiga town, the capital of ESRS, lies 628 kilometers east of Addis Ababa at $9^{\circ} 20^{\prime}$ north latitude and $42^{\circ} 47^{\prime}$ east longitude. The district's elevation extends from 900 to 1600 meters above sea 
level, and the area receives $300-500 \mathrm{~mm}$ of annual rainfall, with typical annual temperatures of $20^{\circ} \mathrm{C}$ and $28^{\circ} \mathrm{C}$, respectively. ${ }^{48}$ The samples are taken from the only Jigjiga municipal slaughterhouse, and a small number of slaughtered camels (3-6) are due to shortages of related facilities. Out of this, only a few females were slaughtered. It has not been possible to ascertain the motives for taking these camels for slaughter because of the nomadic nature of the camel owners in the study field.

\section{Study Animals}

The study animals were dromedary camels (Camelus dromedarius) of both sexes, with different age groups (ranging from 8 to 15 years old) coming mostly from Aweber, Godie, Bable, and Fafen pastoral areas.

\section{Study Design and Sample Size Determination}

An abattoir-based cross-sectional study was carried out to investigate gross pathological disorders and isolate bacterial pathogens from the reproductive organs of fifty slaughtered female camels. Nonprobability sampling methods were used, and the existence of any reproductive organ disorders was investigated postmortem from all slaughtered camels in the abattoir during each visit. We were unable to acquire information about infertility history since the merchants had no information about the previous history of the camels. However, general physical and clinical examinations were carried out before slaughter, paying attention to indications of the reproductive system, such as vulva for any gross lesion, signs of vaginal discharge, and diagnosis of pregnancy.

\section{Sample Collection and Processing}

All-female camels brought to the abattoir were appropriately examined for the presence of any abnormal signs during antemortem and postmortem. The abattoir visit was made three times per week, and during each abattoir visit, approximately 3-6 camels were slaughtered, and 1-2 of them were female camels. Immediately after slaughter, the entire reproductive organ (mass) was carefully and aseptically removed, excised using a sterile surgical blade, and inspected for the presence of gross pathological changes with close attention to the vagina, cervix, uterus, oviducts, and ovaries. To avoid cross-contamination between samplings, single-use sterile instruments (such as sterile blade and forceps) were used during the collection of each sample.
Gross lesion examination was conducted using criteria from Veterinary Medical Teaching Hospital, USA, ${ }^{49}$ in which visual inspection and palpation were used to determine lesion distribution, contour, consistency, texture, shape, scale, and color of the organs, as well as the extent and nature of the exudate contained upon incisions, were recorded in a format prepared for the purpose. Any gross lesions or anomalies found along the reproductive tract (uterus, ovaries, cervix, vagina, oviducts, and bursa) have been reported. The surface of the tissue with the lesion was decontaminated with a moderate hot flame, collected separately in a sterile universal bottle, tagged, and taken to Jigjiga University Microbiology Laboratory for bacteriological investigation. All procedures were conducted according to Quinn et al. ${ }^{50}$

\section{Bacteriological Analysis}

All bacteriological processes were conducted following the standards set by Quinn et al. ${ }^{50}$ The organs were chopped using sterile scissors and forceps, homogenized using a mechanical tissue homogenizer, put into brain heart infusion broth, and placed in a standard incubator for $24 \mathrm{hrs}$ at $37^{\circ} \mathrm{C}$. The bacteria were then streaked on 7\% sheep blood agar and cultured aerobically for additional 24 hours at $37^{\circ} \mathrm{C}$. The plates were then tested for growth and colony morphology, size, and form, as well as the presence or absence of hemolysis. Nutrient and MacConkey agars were used to subculture the colonies.

Catalase, oxidase, oxidation fermentation, motility tests, and Gram staining were used for primary identification. For the suspicious samples from the initial test findings, selective and differential media, such as mannitol salt agar, Edwards' medium, eosin methylene blue (EMB), xylose lysine deoxycholate (XLD), and Salmonella Shigella agar, were utilized. After 24 hours of incubation, the selective medium showed typical growth. A colony was put into brain heart infusion for further biochemical studies. IMViC assays were performed, including the indole test, methyl red test, Voges-Proskauer (VP) test, and citrate test. Secondary biochemical testing included coagulase, aesculin hydrolysis, urease, lysine, and sugar assays, such as glucose, sucrose, lactose, maltose, xylose, trehalose, raffinose, and mannitol. ${ }^{50,51}$

\section{Data Analysis}

All databases on genital bacteria and their isolation rates were recorded on Microsoft Excel 2019 and analyzed using STATA version 13 for descriptive analysis. A descriptive statistic was used to determine the frequency of the isolates and pathological abnormalities of the reproductive organs. 


\section{Results}

\section{Characterization of Gross Lesions in Different Parts of Reproductive Organs}

Out of the 50 female dromedary camels investigated for reproductive organ abnormalities, $36.0 \%(n=18)$ had gross lesions. During sample collection, many forms of reproductive diseases or disorders were identified, including metritis, pyometra (uterine infection owing to the presence of pus), cervix, and vaginal problems.

Accordingly, uterine lesions with an $18.0 \%$ prevalence rate were found to be the most frequently detected abnormalities in the reproductive tracts of the examined camels. Among the uterine abnormalities, metritis and pyometra were found to be the most frequent uterine abnormalities. The second most frequent abnormalities of the examined reproductive tracts were cervical and vaginal disorders $(12 \%)$, followed by ovarian abnormalities $(6 \%)$ (Table 1$)$.

\section{Isolation Rate of Aerobic Bacteria from Reproductive Organ Disorders}

In this study, all $50(100 \%)$ sampled reproductive organs of she-camels were positive for at least one bacterium. Of this, 21 $(42 \%)$ of the samples had only one bacterial isolate. On the other hand, approximately 29 (58\%) of the samples had at least two different bacterial organisms. Organ-wise distribution revealed that $58 \%(29 / 50)$ of isolates were from the uterus, $14 \%(7 / 50)$ were from the cervix and vagina, $8 \%(4 / 50)$ were from the udder, and $6 \%(3 / 50)$ were from the ovary (Table 2 ).

Table I Summary of Type and Frequency Reproductive Organ Abnormalities of Examined She-Camels

\begin{tabular}{|l|l|l|}
\hline Pathological Lesions & Frequency & Percentage (\%) \\
\hline Uterine Lesions & & \\
\hline Acute metritis & 5 & 10.0 \\
\hline Pyometra & 4 & 8.0 \\
\hline Ovarian disorders & & \\
\hline Follicular cyst & 2 & 4.0 \\
\hline Inactive/hypoplastic ovary & 1 & 2.0 \\
\hline Cervix and vaginal disorders & & \\
\hline Cervicitis & 3 & 6.0 \\
\hline Vaginitis & 2 & 4.0 \\
\hline Vaginal lymphocytic mass & 1 & 2.0 \\
\hline Total & $\mathbf{1 8}$ & $\mathbf{3 6 . 0}$ \\
\hline
\end{tabular}

\section{Bacteria Isolated from Various Reproductive Organs}

Overall, eight different types of bacterial isolates were identified from the reproductive organs of she-camels in the study area. The bacteria isolated were coagulasenegative Staphylococcus (CoNs) 25 (50\%), S. aureus 18 (36\%), E. coli 12 (24\%), Streptococcus spp. 11 (22\%), Salmonella spp. 6 (12\%), Proteus spp. 8 (16\%), Shigella spp. 2 (4\%) and Klebsiella spp. 1(2\%). The most prevalent isolated organism was CoNs $25(50 \%)$, while the least prevalent was Klebsiella spp. 1(2\%) (Table 3).

\section{Organ-Wise Distribution of Isolated Bacteria from Different Reproductive Organs}

The organ-wise distribution of isolated bacteria is presented in Table 4. Coagulase-negative Staphylococcus species (CoNs) were the highest bacterial isolates from the cervix, ovary, udder, uterus, and vagina, with proportions of $57.1 \%$,

Table 2 Distribution of Isolated Bacteria from Reproductive Organs of She-Camels

\begin{tabular}{|l|l|l|}
\hline Organ & Frequency & Percent (\%) \\
\hline Cervix & 7 & 14 \\
\hline Ovary & 3 & 6 \\
\hline Udder & 4 & 8 \\
\hline Uterus & 29 & 58 \\
\hline Vagina & 7 & 14 \\
\hline Total & $\mathbf{5 0}$ & 100 \\
\hline
\end{tabular}

Table 3 Bacterial Species Isolated from Reproductive Organ Disorder of She-Camels

\begin{tabular}{|l|l|l|}
\hline Isolated Bacterial Species & $\begin{array}{l}\text { Total No. of } \\
\text { Isolates }\end{array}$ & $\begin{array}{l}\text { Proportion } \\
\text { (\%) }\end{array}$ \\
\hline Coagulase-negative Staphylococcus spp. & 25 & 50 \\
\hline Staphylococcus aureus & 18 & 36 \\
\hline E. coli & 12 & 24 \\
\hline Streptococcus spp. & 11 & 22 \\
\hline Salmonella spp. & 6 & 12 \\
\hline Proteus spp. & 4 & 8 \\
\hline Shigella spp. & 2 & 4 \\
\hline Klebsiella spp. & 1 & 2 \\
\hline
\end{tabular}


Table 4 Organ-Wise Distribution of Isolated Bacteria from Different Reproductive Organs

\begin{tabular}{|l|l|l|l|l|l|l|l|l|l|}
\hline Organs & & CoNs & S. aureus & $\begin{array}{l}\text { Streptococcus } \\
\text { spp. }\end{array}$ & $\begin{array}{l}\text { Salmonella } \\
\text { spp. }\end{array}$ & E. coli & $\begin{array}{l}\text { Proteus } \\
\text { spp. }\end{array}$ & $\begin{array}{l}\text { Shigella } \\
\text { spp. }\end{array}$ & $\begin{array}{l}\text { Klebsiella } \\
\text { spp. }\end{array}$ \\
\hline Cervix & Counts (\%) & $4(57.1)$ & $3(42.9)$ & $3(42.9)$ & $I(14.3)$ & $2(28.6)$ & $0(0.0)$ & $0(0.0)$ & $0(0.0)$ \\
\hline Ovary & Counts (\%) & $2(66.7)$ & $I(33.3)$ & $0(0.0)$ & $0(0.0)$ & $I(33.3)$ & $0(0.0)$ & $0(0.0)$ & $0(0.0)$ \\
\hline Udder & Counts (\%) & $2(50.0)$ & $2(50.0)$ & $0(0.0)$ & $0(0.0)$ & $0(0.0)$ & $0(0.0)$ & $0(0.0)$ & $0(0.0)$ \\
\hline Uterus & Counts (\%) & $14(48.3)$ & $9(31.0)$ & $7(24.1)$ & $4(13.8)$ & $0(0.0)$ & $6(20.7)$ & $2(6.9)$ & $4(13.8)$ \\
\hline Vagina & Counts (\%) & $3(42.9)$ & $3(42.9)$ & $1(14.3)$ & $I(14.3)$ & $2(28.6)$ & $2(28.6)$ & $0(0.0)$ & $1(14.3)$ \\
\hline Total & Counts (\%) & $\mathbf{2 5 ( 5 0 . 0 )}$ & $\mathbf{1 8 ( 3 6 . 0 )}$ & $\mathbf{I I ( 2 2 . 0 )}$ & $\mathbf{6 ( 1 2 . 0 )}$ & $\mathbf{I 2 ( 2 4 . 0 )}$ & $\mathbf{8}(\mathbf{1 6 . 0 )}$ & $0(0.0)$ & $\mathbf{5 ( 1 0 . 0 )}$ \\
\hline
\end{tabular}

$66.7 \%, 50 \%, 48 \%$, and $42.9 \%$, respectively, while the lowest proportion of bacterial isolates (Proteus, Shigella, and Klebsiella species) was isolated from the cervix (Table 4).

\section{Discussion}

Camelids have been shown to have a variety of reproductive abnormalities, which may play a part in their low fertility. ${ }^{52}$ The current study revealed that camels suffer from different infectious diseases, and various types of gross pathological lesions were recorded. The detection of uterine infection is critical in preventing the spread of infection to other animals through venereal transmission. Furthermore, determining the causative agents and their susceptibility to various medications helps practitioners select the most effective treatment. ${ }^{25}$

Similar abattoir-based studies have been conducted in several parts of the globe on reproductive abnormalities of camels by Shawky et $\mathrm{al}^{30}$ in Egypt, Ali et al; ${ }^{38}$ Ali et al, ${ }^{39}$ in Saudi Arabia, Muhammad et al, ${ }^{40}$ in Nigeria, Simenew et $\mathrm{al}^{31}$ in Ethiopia, Benaissa et $\mathrm{al}^{.53}{ }^{5}$ Benaissa et $\mathrm{al},{ }^{41}$ in Algeria, Wajid, ${ }^{43}$ in Iraq and Mustafa et $a l,{ }^{47}$ in Pakistan. All these studies were based on gross lesions, and most microscopic and bacterial cultures were not conducted.

The characterization of gross lesions was carried out depending on distinct lesion characterization attributes. When there are active inflammation and redness (hyperemic) areas, the lesion is classified as acute. Suppurative exudates appeared in the form of pus (creamy yellow), with the afflicted tissue melted into a soft sticky substance. When the majority of the acute metritis lesions were palpated, they were soft. ${ }^{54}$

In the present study, organ-based gross lesions of the reproductive tract abnormality were also conducted. Of the total genital tracts examined, 36\% (18/50) of organs had at least one gross pathological lesion of the reproductive systems. The organ-level pathological lesion of the genital tract was in line with the earlier reports of Getahun et $\mathrm{al}^{52}$ in central Ethiopia that reported $34.2 \%$ and lower than Belina et $\mathrm{al}^{54}$ who reported 64.6\% pathological lesion in Eastern Ethiopia.

The prevalence of macroscopic genital abnormalities found in the current investigation was comparable with the result of Wajid, ${ }^{43}$ with a prevalence of $31.5 \%$ in Iraq. However, the reproductive organ abnormalities recorded in our study were higher than the report of Melaku et al, ${ }^{31}$ who recorded (19.9\%) abnormalities, Benaissa et al, ${ }^{53}$ who reported $(28.8 \%)$, and Shawky et al, ${ }^{30}$ who reported $(26 \%)$ abnormalities from Ethiopia, Algeria, and Egypt, respectively. This difference might be due to differences in management, provision of veterinary intervention, geographic location, and type of diet.

Based on the anatomical classification in the present study, uterine abnormality $9(18.0 \%)$, followed by cervicovaginal abnormality $6(12.0 \%)$, and ovarian abnormality $3(6.0 \%)$ were the most prevalent. The uterine abnormalities 9 $(18.0 \%)$ found in this research were lower than Belina et $\mathrm{al}^{54}$ in Eastern Ethiopia and who reported $41.2 \%$. It was comparable to Getahun et $\mathrm{al}^{52}$ in Addis Ababa, Adama, and Akaki abattoirs and Wajid ${ }^{43}$ in Iraq, who reported $21.4 \%$ and $20 \%$, respectively. However, the finding of the ovarian lesion was 3 (6.0\%), which was lower than Melaku et $\mathrm{al}^{31} 14(6.5 \%)$ in Ethiopia, Wajid, ${ }^{43} 10$ (12.5\%), Hamouda et al ${ }^{46} 61$ (10.16\%) in Saudi Arabia.

The incidence of acute metritis in this research was 5 $(10.0 \%)$, and the current finding was comparable with the report of Melaku et al, ${ }^{31} 13.4 \%$ in Ethiopia and Shawky et $\mathrm{al}^{30}$ $13.2 \%$ in Egypt and Wajid, ${ }^{43} 16(20 \%)$ in Iraq. However, it was lower than Getahun et al, ${ }^{52}$ who reported $39.1 \%$ in central Ethiopia. The disparity might be due to differences in sample 
size, the study period, management systems and veterinary services, as well as nutritional and physiological variables between the camels in the various research areas. Repeated mating of male camels, postpartum problems, and unhygienic genital organ intervention might all contribute to dromedary camel uterine infection. ${ }^{15}$ Severe uterine infection can develop due to aggressive mating at the "wrong" period of follicular growth. ${ }^{23}$ As age increased, she-camels were more predisposed to metritis than younger camels, which is a report by Waheed et al. ${ }^{55}$ This might be because mature animals are more likely to have a repeated number of mating, delivery, and/or frequent postdelivery problems than other age groups.

The prevalence of follicular cysts and inactive/hypoplastic ovaries in dromedary camels was $4 \%$ and $2 \%$, respectively. It was lower than Getahun et $\mathrm{al}^{52}$ in Addis Ababa, Adama, and Akaki (7.14\%) and Belina et $\mathrm{al}^{54}$ in Eastern Ethiopia (35.3\%). This might be related to the fact that dromedary camels are prone to developing follicular ovarian cysts in the absence of coitus. ${ }^{16,24}$ Furthermore, this can be linked to a variety of influencing variables, such as milk production, food, management, and activity, all of which may impact the occurrence of cystic follicles in any animal species. ${ }^{15,56}$ Although the specific origins of ovarian follicular cysts are unknown, it is known that they form when one or more follicles fail to ovulate and then refuse to retreat, allowing development and steroidogenesis to continue. ${ }^{57,58}$

On the other hand, these cysts are thought to be the result of persisting embryonic structures that are remnants of Wolffian ducts. ${ }^{46}$ The low prevalence of inactive ovaries in dromedary camels revealed in this study might be due to the camelids' seasonal mating pattern and the fact that the current investigation was conducted, while most camels were cyclic. It was also proven that the dromedary camel's peak sexual activity occurred between November and February. ${ }^{59}$ The size and weight of the ovaries, on the other hand, may be affected by the animal's age, size, and stage of the reproductive cycle. In juvenile and adult camels, ovarian size is often larger during breeding seasons. ${ }^{60}$

The current research showed that all (100\%) of she-camel reproductive organ samples were infected with at least one bacterium that included coagulase-negative Staphylococcus spp., Staphylococcus aureus, E. coli, Streptococcus spp., Salmonella spp., Proteus spp., Shigella spp., and Klebsiella spp., with isolation rates of 50\%, 36\%, 24\%, 20\%, 12\%, 8\%, $4 \%$, and $2 \%$, respectively. This rate of isolation is in contrast to the study in Egypt by Nabih and Osman, ${ }^{25}$ which found the in contrast to the presence of bacteria were detected in samples $(87.5 \%)$ of endometritis $(92.5 \%)$ of metritis cases. Uterine infections are the most frequent of these disorders, as they appear in so many domestic animal species. ${ }^{16,20,61-64}$ The uterus is exposed to infection risks throughout a shecamel's reproductive life, especially during breeding and after parturition, when various microorganisms are carried into the uterine cavity from the posterior part of the genitalia or the environment, and partial or complete failure of these mechanisms allows the infection to take hold. ${ }^{15,54}$

The most prevalent cause of reproductive failure in Camelidae is uterine infections. ${ }^{65}$ In the uterus, we isolated CoNs (48\%), S. aureus (31\%), E. coli $(24 \%)$, Streptococcus spp. (24\%), Salmonella spp. (13.8\%), Proteus spp. (20.7\%), Shigella spp. (6.9\%), Klebsiella spp. (13.8\%). In the study by Nabih and Osman ${ }^{25}$ in Egypt, the prevalence of Proteus spp. (25\%) is pretty higher than our study, whereas Klebsiella spp. (20\%) and Salmonella spp. (17.5\%) were comparable to our study. In another study by Yagoub, ${ }^{66}$ in Sudan, isolated a very high proportion $(60 \%)$ of $S$. aureus. Other authors have isolated a range of bacterial species from cases of metritis, including Streptococcus zooepidemicus, hemolytic Streptococci, Enterococcus, coagulase-negative Staphylococcus, Proteus spp., Enterobacter aerogenes, Klebsiella pneumoniae, and Arcanobacterium pyogenes. ${ }^{20,64,67-70}$

The high rate of isolation of $S$. aureus in many of the aforementioned authors might indicate the wide distribution of this organism in the environment and consequently, cause many diseases. The outcome of the present study revealed that all sampled (100\%) reproductive organs of she-camels were infected with at least one bacterium that comprised coagulase-negative Staphylococcus spp., Staphylococcus aureus, E. coli, Streptococcus spp., Salmonella spp., Proteus spp., Shigella spp., and Klebsiella spp., with isolation rates of $25(50 \%), 18$ (36\%), 12 (24\%), 10 (20\%), 6 (12\%), 4 (8\%), 2 (4\%) and $1(2 \%)$, respectively. These are indicative of significant bacterial infectious agents of reproductive organs shecamels and important human pathogens.

The vaginal bacterial floras isolated from she-camels in this study were CoNs, E. coli, and Proteus spp. Streptococcus spp., Salmonella spp. and Klebsiella spp. The types of vaginal bacterial isolates in the current study are not in agreement reported from reproductive problems of dairy cows. ${ }^{71}$ From the present study isolates, Staphylococcus spp. which is considered pathogenic to the female genital tract was found to dominate over the others, followed by E. coli and Streptococcus species. These 
isolates of Staphylococcus species are important because Staphylococcus spp. live as commensals of the mucosa of reproductive and respiratory organs and based on a dominant slight agreement with the report Melaku et $\mathrm{al}^{31}$ isolated high proportions of Staphylococcus species from cows with a history of uterine infection.

\section{Conclusion}

Camel reproductive health problems affect reproductivity either by inducing infertility or sterility, which contributes to huge financial losses to pastoralists. The current investigation revealed that one or more bacterial isolates and different pathological lesions were recorded from the genital tract of female dromedary camels slaughtered at Jigjiga Municipal abattoir. During the postmortem examination, $36.0 \%$ of gross pathological lesions were recorded from sampled reproductive organs, and uterine lesions were the most prevalent ones. Additionally, eight different aerobic bacterial genera, namely, Staphylococcus aureus, E. coli, coagulase-negative Staphylococcus, Streptococcus, Salmonella, Proteus, Shigella, and Klebsiella species, were isolated from the genital tract of she-camel. In conclusion, more investigations that recruit a greater sample size in an extended study period should be performed using molecular pathology, microbial sequencing, and hormonal assay techniques. Any gynecological manipulations and procedures should be performed aseptically using sterile equipment. Moreover, the postpartum period should be properly managed, and if any signs of disorders are seen, they should immediately be treated. Provision of training for veterinarians and technicians working in pastoral areas that focus on reproductive health disorders of female dromedary camels.

\section{Abbreviations}

CoNs, coagulase-negative staphylococcus; CSA, Central Statistical Authority; ESRS, Ethiopian Somali Regional State; FAO, Food and Agriculture Organization.

\section{Data Sharing Statement}

The data will be shared upon the corresponding author's request.

\section{Ethics Approval and Consent to Participate}

Ethical clearance was obtained from the Wolaita Sodo University Review Board. The purpose of the study was well explained to the abattoir officials before taking the samples, and informed consent was obtained to take the appropriate sample through verbal consent.

\section{Author Contributions}

All authors made substantial contributions to conception and design, acquisition of data, or analysis and interpretation of data; took part in drafting the article or revising it critically for important intellectual content; agreed to submit to the current journal; gave final approval of the version to be published; and agreed to be accountable for all aspects of the work.

\section{Disclosure}

The authors report no conflicts of interest in this work.

\section{References}

1. Food and Agriculture Organization. FAO Production Yearbook 2001. Rome, Italy: FAO of the United Nations; 2003:333.

2. Central Statistical Agency. Report on Livestock and Livestock Characteristics. The Federal Democratic Republic of Ethiopia, Private Peasant Holdings, Statistical Bulletin 570. Addis Ababa, Ethiopia: CSA; 2017.

3. Yesihak Y, Bekele T. Growth pattern of the one-humped camel (Camelus dromedarius). Proceeding of the 11th Annual Conference of the Ethiopian Society of Animal Production (ESAP) held in Addis Ababa, Ethiopia. Ethiopian Society of Animal Production; 2003:157-165.

4. Workneh N. Socio-economic importance of camel in Ethiopia: an overview. A paper presented on the international workshop on Camel Research and Development: formulating a research agenda for the next decade; Wad Medani, Sudan; 2002:9-12.

5. Bekele T. Studies on the respiratory disease 'sonbobe'in camels in the eastern lowlands of Ethiopia. Trop Anim Health Prod. 1999;31 (6):333-345. doi:10.1023/A:1005290523034

6. Bekele T, Kebebew T. Camel production and productivity in eastern lowlands of Ethiopia. Proceedings of the 9th annual conference of the Ethiopian Society of Animal Production (ESAP). Addis Ababa, Ethiopia; 2001.

7. Getahun T, Belay K. Camel husbandry practices in Eastern Ethiopia: the case of Jijiga and Shinile Zones. Nomad People. 2002;6 (1):158-179. doi:10.3167/082279402782311040

8. Schwartz H, Dioli M. One-Humped Camel (Camelus dromedarius) in Eastern Africa. One-Humped Camel (Camelus dromedarius) in Eastern Africa-A Pictorial Guide to Diseases, Health Care, and Management. J Margraf; 1992.

9. Farah Z, Mollet M, Younan M, et al. Camel dairy in Somalia: limiting factors and development potential. Livestock Sci. 2007;110(12):187-191. doi:10.1016/j.livsci.2006.12.010

10. Mehari Y, Mekuriaw Z, Gebru G. Potentials of camel production in Babilie and Kebribeyah wore-das of the Jijiga zone, Somali region, Ethiopia. ESAP Proceedings; 2007.

11. Seifu E. Handling, preservation, and utilization of camel milk and camel milk products in Shinile and Jijiga Zones, eastern Ethiopia. Livestock Res Rural Dev. 2007;19(6):86.

12. Tegegne A, Gebrewold A. Prospects for peri-urban dairy development in Ethiopia. 5 National Conference of Ethiopian Society of Annual Production; 15-17 May 1997. Addis Ababa, Ethiopia: Ethiopian Society of Annual Production, ESAP; 1998. 
13. Simenew K, Dejen T, Tesfaye S, et al. Characterization of camel production system in Afar pastoralists, North-East Ethiopia. Asian J Agric Sci. 2013;5(2):16-24. doi:10.19026/ajas.5.2579

14. Kaufmann BA. Reproductive performance of camels (Camelus dromedarius) under pastoral management and its influence on herd development. Livestock Prod Sci. 2005;92(1):17-29.

15. Tibary A, Fite C, Anouassi A, et al. Infectious causes of reproductive loss in camelids. Theriogenology. 2006;66(3):633-647. doi:10.1016/j. theriogenology.2006.04.008

16. Tibary A, Anouassi A. Reproductive disorders of the female camelidae. In: Theriogenology in Camelidae: Anatomy, Physiology, BSE, Pathology and Artificial Breeding Actes Editions. Institut Agronomique et Vétérinaire Hassan II; 1997:317-368.

17. Mshelia G, Abba Y, Voltaire Y, et al. Comparative uterine bacteriology and pathology of camels (Camelus dromedarius) and cows in north-eastern Nigeria. Comp Clin Path. 2013;22(6):1195-1200. doi:10.1007/s00580-012-1549-8

18. El-Hawy AS, El-Bassiony MF, Bakr SA, et al. Productive and reproductive performance and metabolic profile of barki ewes supplemented with two forms of probiotics as feed additives. World. 2019;9(2):135-145.

19. Swelum -A-A-A, Alowaimer AN. Comparison of the use of cephapirin and oxytetracycline for the treatment of clinical endometritis in the camel (Camelus dromedarius): a field study. J Anim Veter Adv. 2013;12(4):527-532.

20. Wernery U, Kumar B. Reproductive disorders in dromedary camels due to infectious causes and its treatment. J Camel Pract Res. 1994; 1:85-87.

21. Tibary A, Anouassi A. Uterine infections in Camelidae. Veterinary Sciences Tomorrow. 2001.

22. Tibary A, Anouassi A, Memon M. Approach to diagnosis of infertility in camelids: retrospective study in alpaca, llamas and camels. J Camel Pract Res. 2001;8(2):167-179.

23. Vaughan J, Tibary A. Reproduction in female South American camelids: a review and clinical observations. Small Ruminant Res. 2006;61 (2-3):259-281. doi:10.1016/j.smallrumres.2005.07.015

24. Tibary A, Anouassi A. Reproductive disorders in the female camelid. In: Skidmore JA, Adams GP, editors. Recent Advances in Camelid Reproduction. International Veterinary Information Service; 2000.

25. Nabih A, Osman R. Bacteriological studies of endometritis as a main cause for reproductive and fertility problems in she-camel. Assiut Vet Med J. 2012;58(134):396-402.

26. Refai M. Bacterial and mycotic diseases of camels in Egypt. Proceedings of the First International Camel Conference; 2-6 February 1992.

27. Mekibib B, Desta T, Tesfaye D. Gross pathological changes in the reproductive tracts of cows slaughtered at two abattoirs in Southern Ethiopia. J Veter Med Anim Health. 2013;5(2):46-50.

28. Simenew K, Bekana M, Fikre L, et al. Major gross reproductive tract abnormalities in female cattle slaughtered at Sululta slaughterhouse in Ethiopia. Glob Veterinaria. 2011;6(6):506-513.

29. Abalti A, Bekana M, Woldemeskel M, et al. Female genital tract abnormalities of Zebu cattle slaughtered at Bahir-Dar Town, north-west Ethiopia. Trop Anim Health Prod. 2006;38(6):505-510. doi:10.1007/s11250-006-4319-2

30. Shawky A, Tantawy A, Ibrahim M. An abattoir survey of female genital disorders of camels (Camelus dromedarius) in Kalyoubia, Egypt. 1st Annual Conference, FVM, Moshtohor; 2004.

31. Melaku SK, Melaku M, Feyisa A, et al. Pathological and bacteriological study on abnormalities of female internal reproductive organ of Camelus dromedarius slaughtered at Akaki abattoir, Ethiopia. Am Eur J Sci Res. 2015;10(4):193-202.

32. Buergelt CD. Color Atlas of Reproductive Pathology of Domestic Animals. Mosby-Year Book, Inc; 1997.

33. Chaudhari S, Paul-Bokko B. Reproductive status, pregnancy wastage and incidence of gross genital abnormalities in cows slaughtered at Maiduguri abattoir, Nigeria. Pak Veter J. 2000;20(4):203-205.
34. Tafti A, Darahshiri M. Studies on the uterine abnormalities of slaughtered non-pregnant adult cows. Indian Veter J. 2000;77 (12):1059-1062

35. Ali R, Raza M, Jabbar A, et al. Pathological studies on reproductive organs of Zebu Cow. J Agric Soc Sci. 2006;2:91-95.

36. Argaw A, Bekana M, Regassa F. A gross morphological study of genital organs from female zebu cattle in and around Jimma town (south-west Ethiopia). Animal hygiene and sustainable livestock production. Proceedings of the XVth International Congress of the International Society for Animal Hygiene, Vienna, Austria; Vol 3. Tribun EU; 1353-1355.

37. Gebrekidan B, Yilma T. Major causes of slaughtering of female cattle in Addis Ababa abattoir enterprise, Ethiopia. Indian J Anim Res. 2009;43(4):271-274.

38. Ali A, Al-sobayil FA, Tharwat M, et al. Causes of infertility in female camels (Camelus dromedarius) in middle of Saudi Arabia. $J$ Agric Vet Sci. 2010;2(2):59-68.

39. Ali A, Mehana E, Ahmed A, et al. Ovarian hydrobursitis in female camels (Camelus dromedarius): clinical findings, histopathology and fertility after unilateral surgical ablation. Theriogenology. 2011;76 (3):492-499. doi:10.1016/j.theriogenology.2011.02.028

40. Muhammad B, Aliyu D, Njidda A, et al. Some haematological, biochemical and hormonal profile of pregnant and non-pregnant she-camels (Camelus dromedarius) raised in a Sudan savanna zone of Nigeria. J Camel Pract Res. 2011;18(1):73-77.

41. Benaissa MH, Faye B, Kaidi R. Reproductive abnormalities in female camel (Camelus dromedarius) in Algeria: relationship with age, season, breed and body condition score. J Camel Pract Res. 2015;22 (1):67-73. doi:10.5958/2277-8934.2015.00010.7

42. Mayouf R, Benaissa M, Bentria Y, et al. Reproductive performance of camelus dromedarius in the el-oued region, Algeria. Online J Anim Feed Res. 2014;4(4):102-106.

43. Wajid SJ. A pathological abattoir survey of the reproductive tracts of non pregnant camels (Camelus dromedarius) in Iraq. IOSR J Pharm Biol Sci. 2015;10(3):84-90.

44. Ali HM, Qureshi AS, Hussain R, et al. Effects of natural environment on reproductive histo-morphometric dynamics of female dromedary camel. Anim Reprod Sci. 2017;181:30-40. doi:10.1016/j. anireprosci.2017.03.012

45. Al-Afaleq AI, Hegazy AA, Hussein MF, et al. Pathological disorders of the female reproductive system in slaughtered camels (Camelus dromedarius) in Saudi Arabia. Comp Clin Path. 2012;21(3):245-251.

46. Hamouda MM, Al-Hizab FA, Hasseeb MM. Pathologic studies on ovarian abnormalities in nagas (Camelus dromedarius) in Al-Ahsa, Saudi Arabia. Sci J King Faisal Univ. 2011;12(1):265-276.

47. Mustafa MYS, Chaudhry HR, Chaudhry M, et al. Biometry and pathology of internal genital organs of female camel (Camelus dromedarius) in Lahore, Pakistan. IJIR. 2016;2(8):1028-1034.

48. Central Statistical Authority. Federal Democratic Republic of Ethiopia, Central Statistical Investigatory, Statistical Report. Central Statistical Authority; 2003.

49. VMTH. Anatomic Pathology Service, Senior Veterinary Student Rotation Hand Book. Davis, CA, USA: Veterinary Medical Teaching Hospital; 2009.

50. Quinn PJ, Markey BK, Leonard FC, et al. Veterinary Microbiology and Microbial Disease. John Wiley \& Sons; 2011.

51. Quinn P, Carter M, Markey B, et al. Clinical Veterinary Microbiology. Ed., Mosby, London: John Wiley \& Sons; 1998.

52. Getahun AM, Hunderra GC, Gebrezihar TG, et al. Comparative study on lesions of reproductive disorders of cows and female dromedary camels slaughtered at Addis Ababa, Adama and Akaki abattoirs with bacterial isolation and characterization. BMC Vet Res. 2021;17 (1):1-15. doi:10.1186/s12917-021-02822-z

53. Benaissa MH, Faye B, Kaidi R. Ovarian hydrobursitis in slaughtered female camels (Camelus dromedarius) in Southeast Algeria. Emir J Food Agric. 2014;26(10):915-920. doi:10.9755/ejfa.v26i10.17611 
54. Belina D, Eshetu A, Alemu S, et al. Reproductive diseases and disorders of female camels: an assessment and pathological and bacteriological study in Eastern Ethiopia. Vet Med Int. 2021;2021:14. doi:10.1155/2021/6641361

55. Waheed M, Hamouda M, Al-Dughaym A. Uterine histopathological findings of infertile female camels (Camelus dromedarius). J Camel Pract Res. 2009;16:1-7.

56. Herenda D. An abattoir survey of reproductive organ abnormalities in beef heifers. Can Veter J. 1987;28(1-2):33.

57. Hegazy AA, Ali A, Al-Eknah M, et al. Studies on pituitary-ovarian axis in the female camel with special reference to cystic and inactive ovaries. J Camel Sci. 2004;1:16-24.

58. Vanholder T, Opsomer G, De Kruif A. Aetiology and pathogenesis of cystic ovarian follicles in dairy cattle: a review. Reprod Nutr Dev. 2006;46(2):105-119. doi:10.1051/rnd:2006003

59. Monaco D, Padalino B, Lacalandra GM. Distinctive features of female reproductive physiology and artificial insemination in the dromedary camel species. Emir J Food Agric. 2015;27:328-337. doi:10.9755/ejfa.v27i4.19904

60. Ali S, Ahmad N, Akhtar N, et al. Effect of season and age on the ovarian size and activity of one-humped camel (Camelus dromedarius). Asian Austra J Anim Sci. 2007;20(9):1361-1366. doi:10.5713/ajas.2007.1361

61. Fowler ME. Medicine and Surgery of South American Camelids: Llama, Alpaca, Vicuna, Guanaco. Iowa State University Press; 1998.

62. Johnson LW. Llama reproduction. Veter Clin North Am. 1989;5 (1):159-182.
63. Nur HM. Some Reproductive Aspects and Breeding Patterns of the Somali Camel (Camelus dromedarius). Camel Forum (Sweden): Nordiska Afrikainst; 1984.

64. Wernery U, Wernery R, Allen W, et al. Uterine infections in the dromedary camel-a review. Proceedings of the First International Camel Conference. 1992:155-158.

65. Fowler M. Parasites, Medicine and Surgery of Camelids. Iowa: Blackwell Publishing; 2010.

66. Yagoub SO. Bacterial diseases of the reproductive system of camels (Camelus dromedarius) in Eastern Sudan. J Anim Veter Adv. 2005;4 (7):642-644.

67. Chauhan R, Kaushik R, Satija K. The bacterial spectrum of reproductive tract of camels. J Remount Vet Corps. 1987;26:1-5.

68. Enany M, Hanafi M, El-Ged A, et al. Microbiological studies on endometritis in she-camels in Egypt. J Egypt Vet Med Assoc. 1990;50:229-243.

69. Tibary, A., Fite, C., Anouassi, A., \& Sghiri, A. (2006). Infectious causes of reproductive loss in camelids. Theriogenology. 66(3), 633647.

70. Powers B, Johnson L, Linton L, et al. Endometrial biopsy technique and uterine pathologic findings in llamas. $J$ Am Vet Med Assoc. 1990;197(9):1157-1162.

71. Gani M, Amin M, Alam M, et al. Bacterial flora associated with repeat breeding and uterine infections in dairy cows. Bangla J Veter Med. 2008;6(1):79-86. doi:10.3329/bjvm.v6i1.1342

\section{Publish your work in this journal}

Veterinary Medicine: Research and Reports is an international, peerreviewed, open access journal publishing original research, case reports, editorials, reviews and commentaries on all areas of veterinary medicine. The manuscript management system is completely online and includes a very quick and fair peer-review system. Visit http://www.dovepress.com/testimonials.php to read real quotes from published authors. 